\title{
Herpes zoster mandibularis
}

\author{
Julien Wen Hsieh, ${ }^{1}$ Pedro Costa de Araujo, ${ }^{1}$ Jérôme Lechien, ${ }^{2}$ Jérôme Keghian ${ }^{1}$
}

${ }^{1}$ Department of

Otorhinolaryngology, Luxembourg Hospital Center Luxembourg, Luxembourg ${ }^{2}$ Laboratory of Anatomy and Cellular Biology, Faculty of Medicine, University of Mons, Mons, Belgium

\section{Correspondence to} Dr Julien Wen Hsieh, hsiehjulien@gmail.com

To cite: Hsieh JW, Costa de
Araujo P, Lechien J, et al.
BMJ Case Rep Published
online: [please include Day
Month Year] doi:10.1136/
bcr-2013-200136

\section{DESCRIPTION}

A 54-year-old man presented with vesicular rash and burning pain on the left mandibule. Two days before, the patient had developed pruritus in the same region. Clinical examination revealed vesicles on an erythematous base on the left lower lip, cheek, chin (figure 1), anterior scalp around ear and the ascending helix (figure 2). The lesions were localised in the dermatome innervated by the third trigeminal branch. No oral lesion, facial palsy or hearing loss was observed. A clinical diagnosis of herpes zoster mandibularis was made. The patient was treated with intravenous acyclovir, analgesics and broad-spectrum antibiotics during 10 days for bacterial superinfection. At 2 months follow-up, the rash had resolved and no potential complication was reported.

Varicella zoster virus is responsible for chickenpox and can remain in a latent stage in any sensory ganglia. Reactivation of the virus decades later can occur in a precise dermatome. Rarely, this condition known as herpes zoster is limited to the third trigeminal branch. The patient may describe pain, burning or itching in this dermatome. It is followed by apparition of pustulo-vesicular rash in the same area, which is pathogmonic. The diagnosis can be confirmed by direct immunoflurescence from swabs. Taste dysfunction is also reported. ${ }^{1}$ When rash does not occur, unilateral oro-facial pain may be the only sign and serological examination and PCR technology may be required. $^{2}$ It can be

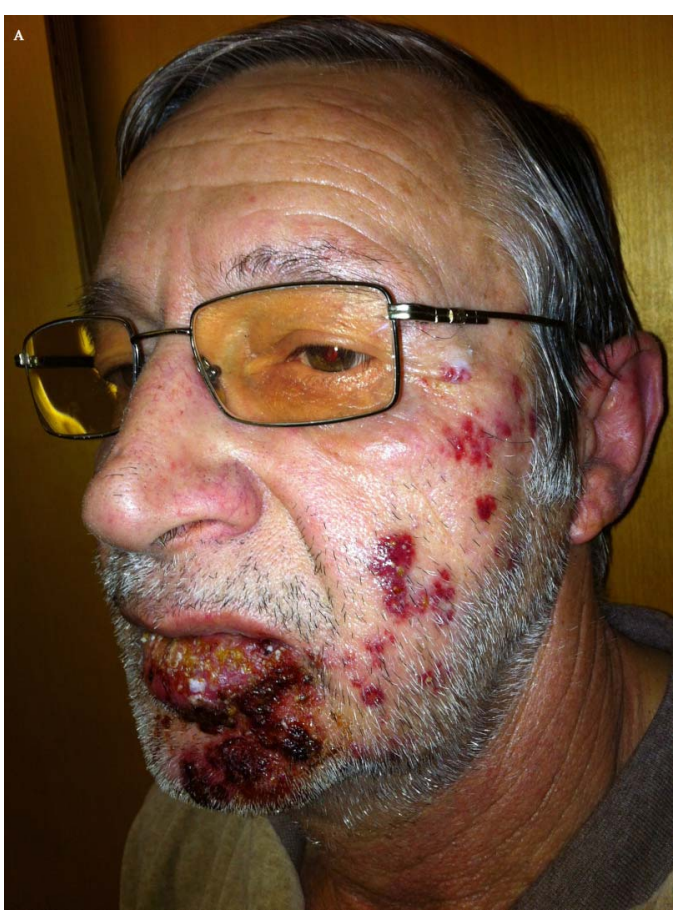

Figure 1 This illustration shows vesicles on an erythematous base on the left lower lip, cheek and chin.

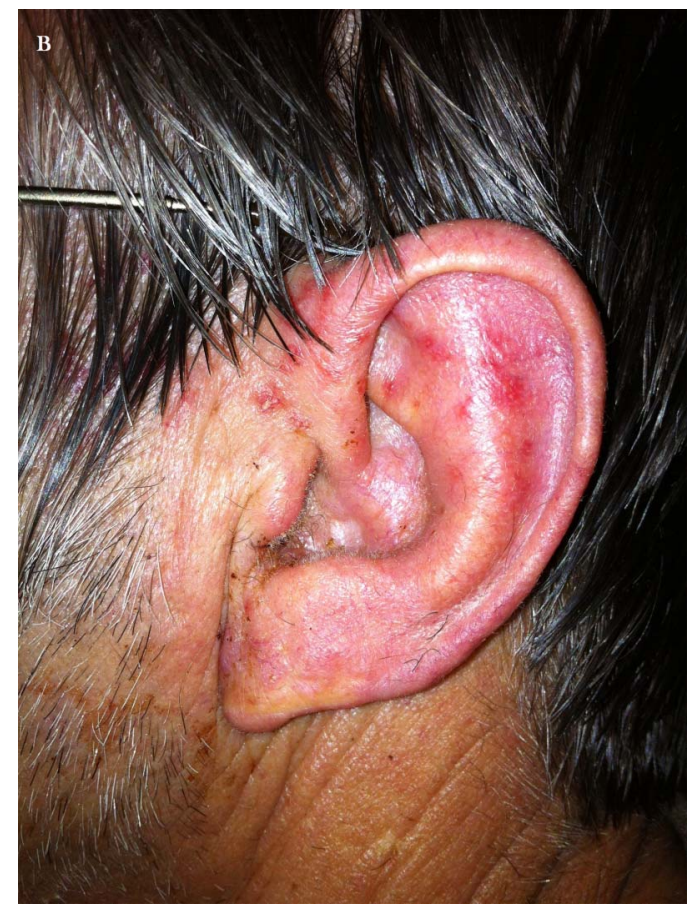

Figure 2 Clinical examination revealed vesicles on an erythematous base on the left anterior scalp around ear and the ascending helix.

complicated by postherpetic neuralgia, tooth exfoliation and mandibular osteonecrosis. ${ }^{3}$ The treatment is acyclovir and should be started within $48 \mathrm{~h}$ of the onset of the rash.

\section{Learning points}

- Herpes zoster limited to the third branch of the trigeminal nerve is a rare presentation of reactivation of varicella zoster virus and can occur with or without vesicular rash.

- Herpes zoster mandibularis sin herpete (without rash) manifests as a unilateral facial or oral pain and its diagnosis is often difficult. Taste and serological evaluation may be of value in differential diagnosis of unilateral facial pain.

- Postherpetic neuralgia, tooth exfoliation and mandibular osteonecrosis are serious complications of this condition. Medical doctors should be aware of its potential evolution and assess careful dental evaluation.

Contributors JWH and PCdA were involved in patient care. All authors contributed significantly to the manuscript.

Competing interests None. 
Patient consent Obtained.

Provenance and peer review Not commissioned; externally peer reviewed.

\section{REFERENCES}

1 Heymans F, Lacroix JS, Terzic A, et al. Gustatory dysfunction after mandibular zoster. Neurol Sci 2011;32:461-4.

Copyright 2013 BMJ Publishing Group. All rights reserved. For permission to reuse any of this content visit http://group.bmj.com/group/rights-licensing/permissions.

BMJ Case Report Fellows may re-use this article for personal use and teaching without any further permission.

Become a Fellow of BMJ Case Reports today and you can:

- Submit as many cases as you like

- Enjoy fast sympathetic peer review and rapid publication of accepted articles

- Access all the published articles

- Re-use any of the published material for personal use and teaching without further permission

For information on Institutional Fellowships contact consortiasales@bmjgroup.com

Visit casereports.bmj.com for more articles like this and to become a Fellow
2 Barrett $\mathrm{AP}$, Katelaris $\mathrm{CH}$, Morris JG, et al. Zoster sine herpete of the trigeminal nerve. Oral Surg Oral Med Oral Pathol 1993;75:173-5.

3 Mendieta C, Miranda J, Brunet LI, et al. Alveolar bone necrosis and tooth exfoliation following herpes zoster infection: a review of the literature and case report. J Periodontol 2005:76:148-53. 